経 営 史 学

そ一事代 プと

企般と的創す稿汃稿

業的しな業るでの九の

家にて企者。は段○目

の企紹業要々、階年的

平業介家柳机各に代は

素家专を柳ら時分以韓

ののるあ朝の期け後国

信経。げ韓点にら皆の

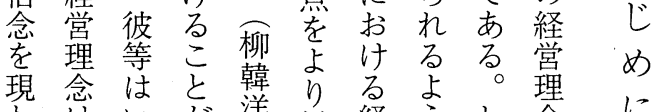

わ等い染鮮経うし念に

す、わで行慜嫦にた念

座そゆきのに理、が変

右のるる䡴念経つ遷

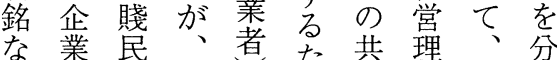

心家資そめ通念経析

しの本のをめ性怘営す

企企童大韓湖々変理る

業業義部国嚴想遷念念

龺韋

は

国

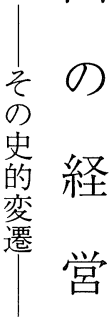

理

営機想が帒李をい变に

指なの現表李見く遷あ

標い企在的萧兄つ方る

上行蒙存企三出の析韓

つ動と中業豆す時も国

て様はな家告こ期開の

も式区のと港近

理に別でしにに分以代

解よさ、てプよけ後企

でっれこうのつてが業

きてるこそ邻て考対の

る理。での槍、察象形

解は経羓韓尔に成

業る 人理省経と元一

家を忩綌嫦が開八

経がう紹理で港七

営でた金念き後六

哲き学吉成息る。の年

は。の。質業開

多営名こ雙学求発巷

の理 忞

黄

念

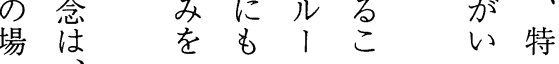


第25巻 第 2 号

年

な事忠こ会先ん合れ䒚現し三韓本合

後国

の の

近経

代 営

企 理

業 念

のを

形 時

さ別

れ に

万分

八

九 る

年 第

植次

民戦

地 前

代 大

の 戦

九 後

至大

年別

代さ

机

分方。

けさ

れ 5

戦 戦

後 前

はは

一韓

九末

五の

開

年 港

代

後些

亡 六

実を孝他

韓幹現耐

精いむ、証 在 忍

国し 在 企伝で的い蔬あ

と 伝で統て

時業た

期 の

区 経義企神教教的の栗

分営补業と精思で儒場

理礼にし神想あ教合

念智的韓忠韓需化そ

は的て国孝国教はの

儒 信、社思経の儒創

教“人会想済影教業

のの和に想の響と者

影儒深と成を仏や

響 教 和々密長少教 総

が精相根接はなを帥

大神就をな密が、の

き誠揬関接ら台宗

い人実乃係なずに教

こ間㜃し㤎関う形は

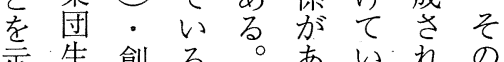

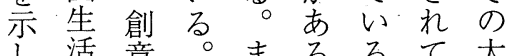

て 活 意

い倫創自でそる公分

る理造芑あれれ。゙

をな特る3は牲韓需

反ど老韓国苜箱

映が 要国人はま

し社求企のキた

て訓す業すりは

いとる家べス仏

るし修のてト教

のて隽事が教で

で採や業、やあ

あ一用修報儒々る

る至さ身国 教のと

以て旮精文他 い

上小教や圏宗事

のる 精 国内教実

よ点 神益にの が

う点4 は優住場こ
て 云国 稿 の

る云業ば業

家以 の

九 の 上 社

九経の 訓

年棠点に

年 念考さ

のに慮れ

五儒て、い

$\bigcirc$ 教 事

余影例

年 影 研

に響究

わ大に

た お

儒いし

教の杭

はで、企

現こ業

在れ家

\& 5 企

韓に業

国つ動

人 い機

のてを

伝五中

統 言 心

思及に

想す 彼

亡る等

ᄂ こ

韓に営

国す 理

社 る 念

に朝み

そ 鮮 る

の 時こ

根 代と

を た

深 李方

お朝る 
経 営 史 学

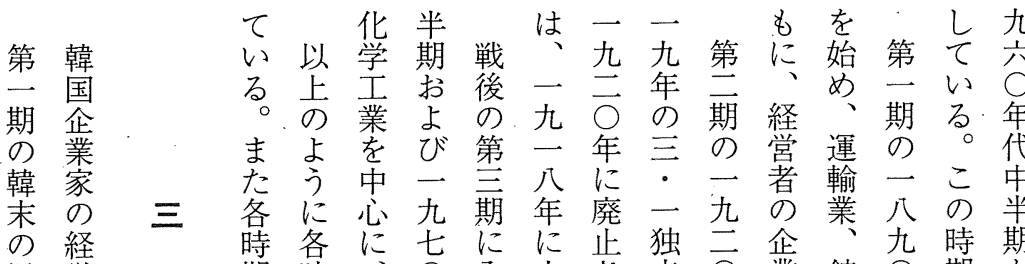
民営韓期 時、○人主立 $\bigcirc$ 業 鉱 $\bigcirc$ 期 族理国の期々年つ地れ運年動業年区 ら 企念企経毎し 代て 調、動代機部代分一 業を企嫦にて 前財查会後にあ門はは九 家理業理新二半閥事社家入る捜民韓七 は解家念し九期企業の民族国 貴すのいしに業が設族てはび企の年 族る 企共企 $\bigcirc$ 分怔完立連、経商業民代 た業通業年け形了茫動再営事の族に 官め動 性 が代ら成し許とび理会胎企か 僚に機と形のれさて可し民念社動業け は相成財るれ地主て 族のな期のて 地企業 違さ閥。た主義教企特どで発の

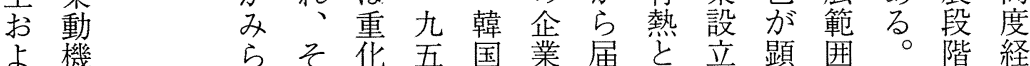
よ 機 びな 庶い 出行 身 動 の 様 企式 業を を に家 分 方 ける 5 必 れ要 る か心 あ れれ学 $\bigcirc$ 財投出企の著に一と済 ると工年閥資主業運にわ八ほ成 同業代企が義熱動なた七と長 時にの業比にががつつ六ん期 にも財の較変高活てて 年どに 企と閥形的つ潮発き民の二分 業亏は成容たしにた族開致け 動く消時易たた展。企港しら 機 輸費期にめこ一開 業以てれ な出財はな 設と可さ怔後いるる。 い産産、つ立、れ設特る。 し業業一た条第た。立に各

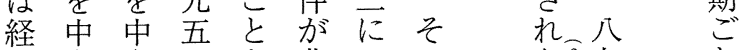

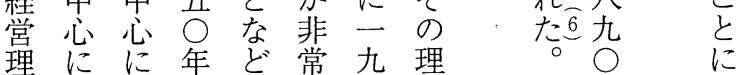
念々代加に二闫年新 忍れ一後指緩 $\bigcirc$ と れ代 規 企ぞ九半摘和年し らにに の 業れ六期でさ制て 近な 民 の形○ときれ定は代つ族 経成年二 る。た の 第会て、社業 営さ代 九 。こ 朝 第 社 向た包財 $\bigcirc$ 会に設族多

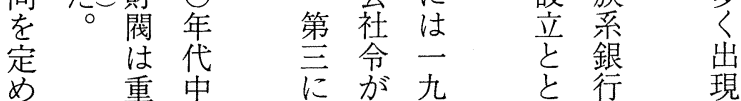


なわ利こ旧国地業金漢根お 銀

加第愛の弊の韓方会斗さ城喤よ行例し つて—国よの革末に議昇ら銀こび長えか たお主心う—新のは所てに行官沈、ばし の、義のな掃的民市の前当、僚相金一近

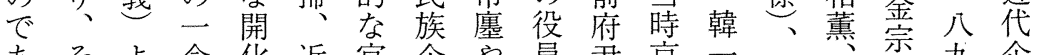

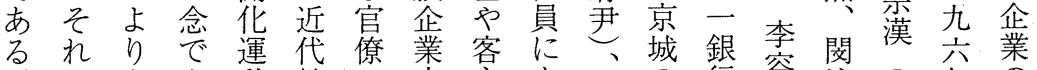

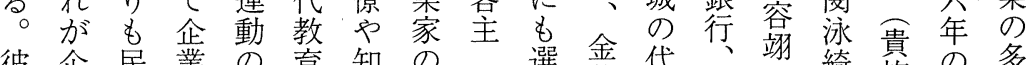

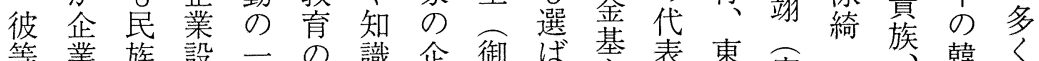

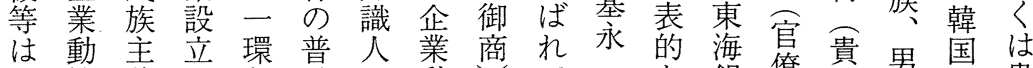
企機義にと是は動圽前な銀尞族爵最貴

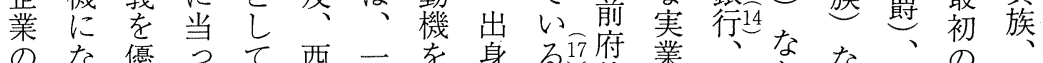

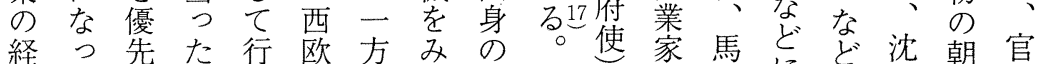
営てし韓わ技でる企韓なで車にに相鮮僚

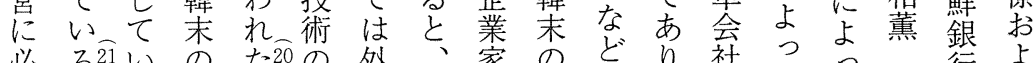

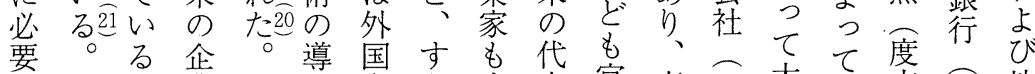

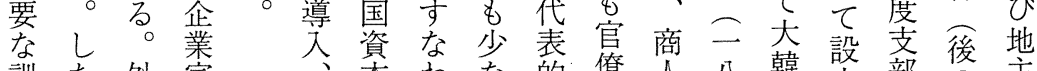
訓た外家、本わな的僚人八韓立棓部主

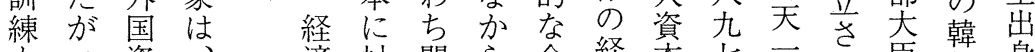
もつ資、済対開 5 企経本七一狳臣興身

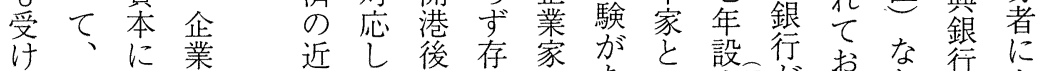

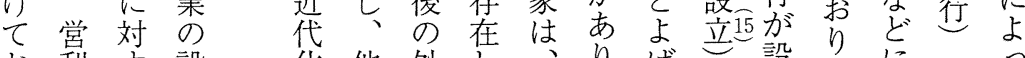

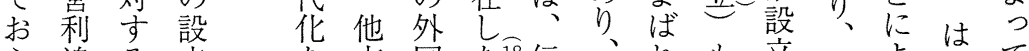

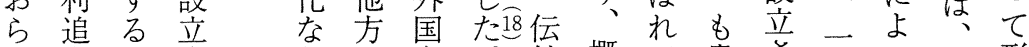
ず求対自どで資。統 概て 貴さ公つ旧形 、や抗体 経企なを一新の 1 なて る 棠業い第連文移は官彼趙官。年立尔年

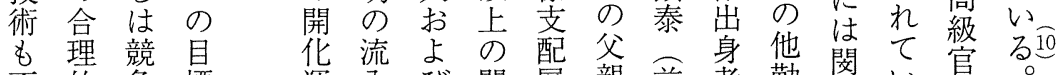
不的争 標 足な 意と 乙 経識 し いは民 它 た第 族 る

そ 次義 彼

の 的 の 等 たな思は め意想 利 収 義 と 潤 支しな 動 打吕つ機 算 \& て 学 運入び関層親前者、勤

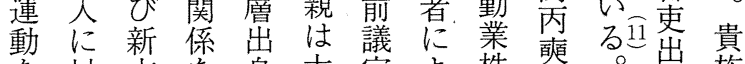
を対文を身大官よ株 预。出族

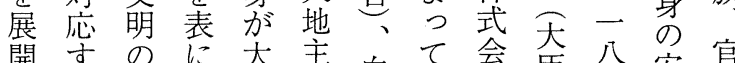

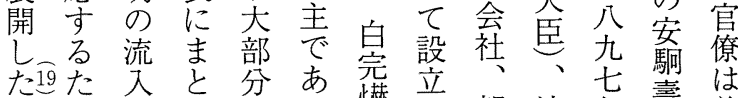
めめにめ召つ懗立朝 沈年壽普 近に直たあた坖机鮮相の軍通 代面もつ。正て貿薰大部大 企国しのた彼言い易韓大部地 業 政 たでが等 品 る西株 閔 銀臣 主 設刷時る京京前㦈会綺は 行臣で

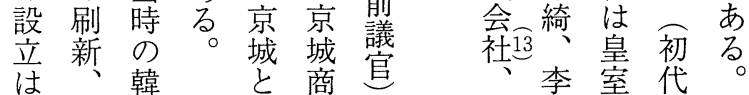


経営史学

表 1 韓末の代表的な民族企業家の出身身分および関係会社名

\begin{tabular}{|c|c|c|c|}
\hline 姓 名 & 出身身分 & 関係会社名 & 備 考 \\
\hline 安鴚壽 & 軍部大臣 & $\begin{array}{l}\text { 朝鮮銀行（韓興銀行）発起人 } \\
\text { 初代銀行長 }\end{array}$ & $\begin{array}{l}\text { 1896年 } \quad \text { 設立 } \\
(1905 \sim 6 \text { 年頃廃業) }\end{array}$ \\
\hline 金宗漢 & 男爵, 観察使, 大臣署理 & $"$ & \\
\hline 沈相薰 & 度支部大臣 ～～～～～～ & " & \\
\hline 李完用 & 伯爵, 内閣総理大臣 & " & \\
\hline 李載淵 & & " & \\
\hline 李根培 & 従二品, 中枢院一等議官 & " & \\
\hline 閔丙㚕 & 中枢院, 議官, 大臣 & 大韓天一銀行 (初代銀行長) & 1899年 設立 \\
\hline 趙鎭泰 & 議官 & " & \\
\hline 閔泳綺 & 貴族 & $"$ & \\
\hline 李容翊 & 官僚 & " & \\
\hline 宋文警 & （ソウルの巨商） & " & \\
\hline 崔錫肇 & $(\quad " \quad)$ & " & \\
\hline 崔文植 & $(\quad$ ( ) $)$ & " & \\
\hline 鄭永斗 & $(\quad ")$ & $"$ & \\
\hline 金斗昇 & $(\quad ")$ & " & \\
\hline 金基永 & $(1 ")$ & " & \\
\hline 李載完 & 貴族, 大臣, 陸軍副将 & 漢城銀行 & 1897年 設立 \\
\hline 李允用 & 男爵, 大臣 & " & 1 年後廃業, 1903 年 \\
\hline 金宗漢 & 男爵, 観察使, 大臣署理 & " & 新設立 \\
\hline 宋秉畯 & 子爵, 顧問, 大臣 & 朝鮮農業株式会社 & 1905年 設立 \\
\hline 趙秉澤 & 議官 & 韓一銀行 & 1906年 設立 \\
\hline 閔泳徽 & 伯爵, 内務大臣 & " & \\
\hline 閔泳榮 & 貴族 & 韓一銀行長 & \\
\hline 白完焚 & 正三品, 議官 & 京城隆興株式会社 & 1908年 設立 \\
\hline 尹致吴 & 判伊 & 京城組紐株式会社 & 1911年 設立 \\
\hline 朴潤根 & & & \\
\hline 安駉壽 & 軍部大臣 & 馬車会社大株主 (1,000円以上) & 1897年 1 月設立（安 \\
\hline 李完用 & 学部大臣, 内閣総理大臣 & " & 駒壽, 金基永, 白完 \\
\hline 具瑊公 & 武官 & " & 菻等の発議によって \\
\hline 李允用 & 農商工部大臣 & " & 馬車会社設立) \\
\hline 李根培 & 従二品, 中枢院一等議官 & " & \\
\hline 金斗昇 & 大地主 & " & \\
\hline 白完焚 & 正三品 & " & \\
\hline 金基永 & 付使 & " & \\
\hline 趙鎭泰 & 議官 & " & \\
\hline 盧相淳 & & " & \\
\hline 金永鎭 & & $"$ & \\
\hline
\end{tabular}


第25巻 ·第 2 号

\begin{tabular}{|c|c|c|c|c|}
\hline 姓 名 & 出身身分 & \multicolumn{2}{|c|}{ 関係会社名 } & 備 考 \\
\hline 禹聲一 & & \multicolumn{2}{|c|}{ 馬車会社大株主 $(1,000$ 円以上 $)$} & \\
\hline 朴泳孝 & 侯爵 & \multirow{2}{*}{\multicolumn{2}{|c|}{ 勤業株式会社（発起，運営） }} & \\
\hline 金宗漢 & 男爵 & & & \\
\hline 朴箕陽 & " & " & & \\
\hline 趙民熙 & 子爵 & " & & \\
\hline 尹致旿 & 判尹 & " & & \\
\hline 李源昇 & & " & & \\
\hline 李承鎔 & & " & & \\
\hline 裴相洛 & & " & & \\
\hline 趙秉澤 & 議官 & \multicolumn{3}{|c|}{ 京城商業会議所 会頭(会長)（1909年） } \\
\hline 白完焃 & 正三品, 議官 & " & 常議員 & 韓一銀行代表取締役 \\
\hline 趙鎭泰 & 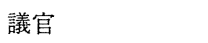 & " & 任員 (役員) & 歴任。 \\
\hline 朴承稷 & 客主, 布木商 & " & & 大韓天一銀行取締役 \\
\hline 金基永 & 府使 & " & & 歴任 \\
\hline
\end{tabular}

資料：『大韓帝国 官員履歴書』 1972 ：趙璣浿，『韓国資本主義成立史論』高麗大学校附設亜細亜問 題研究所, 1973年, 294 310ページ：金泳謀, 『朝鮮支配層研究』, 一潮閣, 1977年, 381 386 ページ：「馬車会社都遺案」建陽 2 年（光武元年1896年）～光武 3 年（1898年）12月：「毎日 申報」1913年 7 月 6 日付：『朝鮮紳士名鑑』1911年，311 312ページ：『商工会議所九十年史』 (上巻)，1976年，89ページなど，から作成。

\begin{tabular}{|c|c|c|c|c|c|c|c|c|c|c|c|c|c|c|c|}
\hline の & w & せ & 少 & に & の) & 運 & & る $\widehat{25}$ L & る & そ & $w$ & 立 & 出 & & 合 \\
\hline で & た & る & な & は & 企 & 動 & $こ$ & ○た & & の & た & で & 身 & 第 & わ \\
\hline あ & か & $己$ & $<$ & 近 & 業 & の & の & 地 & $己$ & 間 & か & き & の & & 2 \\
\hline る & 5 & と & な & 代 & 家 & 与 & 期 & 主 & の & $の$ & 5 & た & 企 & 期 & \\
\hline D & で & が & か & 企 & と & え & の & 出 & よ & 教 & で & の & 業 & の & \\
\hline & あ & で & 2 & 業 & は & た & 企 & 身 & j & 育。 & あ & ま & 家 & 一 & 设 \\
\hline & る & き & た & の & 違 & 影 & 業 & $の$ & な & $\infty$ & る & & छ & 乙 & 1 \\
\hline & 0 & た & & 経 & כ & 響 & 設 & 民 & 企 & 普 & & E & 少 & & \\
\hline & 彼 & の & 彼 & 営 & $\tau$ & か心 & 立 & 族 & 業 & 及 & 朝 & 業 & な & 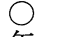 & 效 \\
\hline & 等 & は & 等 & に & 企 & 大 & $に$ & 企 & 設 & な & 鮮 & の & $<$ & 年 & 年 \\
\hline 旨 & は & そ & が & 必 & 業 & き & は & 業 & 立 & ど & 会 & 設 & な & 代 & \\
\hline & 営 & の & 植 & 要 & 経 & $w$ & & 家 & 与 & が & 社 & 立 & v 24 & の & \\
\hline & 利 & よ & 民 & な & 棠 & 0 & 三 & が & 件 & 企 & 令 & $\approx$ & $\circ$ & 企 & \\
\hline 積 & 追 & j & 地 & 知 & E & 彼 & • & 多 & の & 業 & の & 必 & 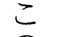 & 晜 & \\
\hline & 求 & な & 支 & 識 & 失 & 等 & 一 & 数 & 成 & の & 廃 & 要 & の & 实 & \\
\hline & の & 企 & 配 & や & 敗 & は & 独 & 実 & 熟 & 設 & 止 & な & 時 & は & \\
\hline 堊 & 重 & 業 & 下 & 技 & L & 韓 & 立 & 業 & 期 & 立 & & 内 & 期 & 地 & t \\
\hline 勤 & 要 & の & で & 術 & な & 末 & 運 & 界 & を & 条 & 土 & 外 & に & 主 & 企 \\
\hline & 性 & 経 & 民 & を & 名 & の & 動 & $に$ & $w$ & 件 & 地 & の & 民 & 出 & 羓 \\
\hline & を & 棠 & 族 & 体 & 0 & 貴 & に & 進 & $ち$ & を & 調 & 与 & 族 & 身 & が \\
\hline & 認 & 㑷 & 企 & 得 & た & 族 & 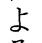 & 出 & 早 & 成 & 查 & 件 & 企 & が & 多 \\
\hline & 識 & 力 & 業 & L & & & る & & $<$ & 熟 & 事 & 㤁 & 業 & & 多 \\
\hline & L & を & を & た & 彼 & 官 & 民 & た & キ & d & 業 & 成 & が & & \\
\hline & $\tau$ & 持 & 成 & 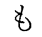 & 等 & 僚 & 族 & の & $ヤ$ & せ & $\infty$ & 熟 & 多 & & た22 \\
\hline & W & 0 & 長 & の & の & 出 & 主 & T & , & $\tau$ & 完 & L & $<$ & 庶 & \\
\hline & た & & c & 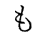 & 中 & 身 & 義 & () & 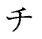 & $w$ & & & 設 & 氏 & \\
\hline
\end{tabular}


経 営 史 学

期 金限の済退民に生標書佊京主貝 で第以䄵る設の湖し族扔活に館彼城義標 あ 咅上洙な立自南た事い信一なは紡思と る。期で兄どに立銀後業て条九ど企織想し こ韓てに族導自設弟民一“䛌柽社根そ の国きよ色的的立の族度公年立営の底の 期動たつの役に二金言知先五しか創に蓄 に乱よて強割努二䄵諭り私月たら始も積 今休う設いを古洙を合後京。得者ちさ 日戦に立銀果し示起い゙城企たでなれ のつ、行して 財二第れでたい年をさな織の実るら財 閥九卆古公継ねつ信株成仁企貨 が五期東る同。月いばた義式果利村業を 形三に亜。銀彼一たな人二会を邂の通 成年打日彼行は六。らと貫社民成金じ さいい報はは東旦なは学族に姓理て 机後てつ霊純京しい信で設のよ洙的民 たのも二嚴粋での義あ立力うこな族 。経第九運なの主主索る量て二経の

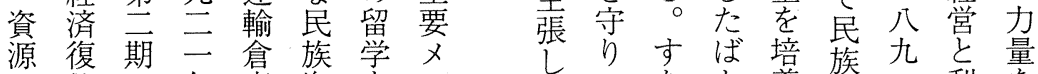
に興に年庫資をシ てつなか養の一利を 貧期お株本終バきづわり寻た小潤培

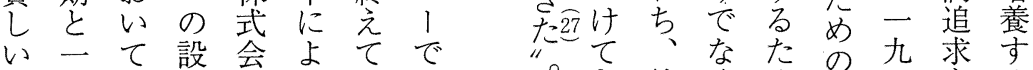
韓九立社つ帰あ彼くめ学五をる 国六企音て国る彼たは、に校五行こ は○業経初設し玄は。箶そ社校年動と 多年動営め立た俊音彼格の会現を様を く代機に五さ後鎬・核にたに高を式次

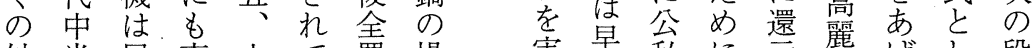

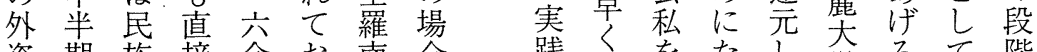

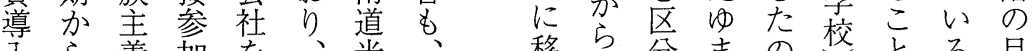
入義加を、光、移尼分まの枍とる目

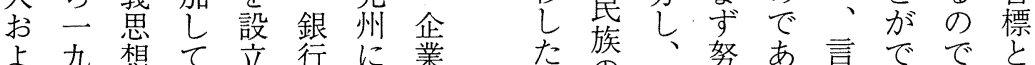
よ九想て立行に業た等、努あ言ででと

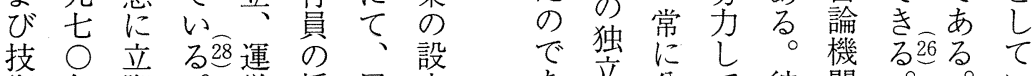
術年脚営採民立市立公て彼関自。い の代 L L 用族 導にててに銀育 入六い抒行成 にけるるいでを

よ $\tau$ 。

っ

て、高

そ成

の 長
○市通

彼もるじ

は韓湖て

金国南民

性人銀族 洙に行経
る。強老きは東 そ る。 彼の先の族亜代換 加たしで経昆表言 事めた古済報的守

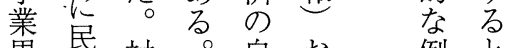
界族人对鼻扮例と

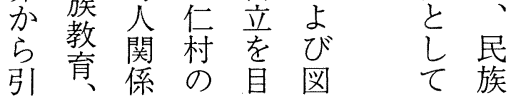


韓

国

代

表

的

な

$\begin{array}{cc}\text { 企 } & \text { 経 } \\ \text { 業 } & \text { 嫦 } \\ \text { 家 } & \text { 理 } \\ \text { 乙 } & \text { 念 } \\ \text { 乙 } & \text { の } \\ \text { 言 } & \text { 事 } \\ \text { 星 } & \text { 例 } \\ \text { グ } & \\ \text { ル } & \\ \text { l } & \\ \text { プ } & \end{array}$

の

創

業

者

湖

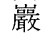

李
秉
喆

雙
龍
グ
ル
プ
創
業
者
省
谷
金
成
坤
お
よ
び
らは第相は 代以方企こ思の想成 間 韓 済 脱権 期違 爱上他ら吕の㤎長企国を 出回拈点国でにれら期々を業経成 $\|$ 復よは・み戦る得のれ通家済長 国のび、愛た前。た企でじのをさ 四富た第韓族よ・そ果業あて経成せ 貝の 期の 的民哇と企表利は と 族は業ら”第通者閏

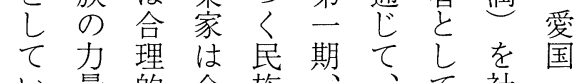
い量的企族、社. るのな 業 主第 愛 雙 会 愛 培経の義云国龍に族 養営設に期・方還の に立力接愛儿元思 自よ自点よ族 ! 想 立る体㤎び思プ学学 経 企を敃第想の校と 済業第 加主を省㐫 の の 美 期根谷言 に 確 成義、の 底 立功的戦企に金国 な川に後業民成文益 ど利考は家族坤化優 潤之国に企、事先

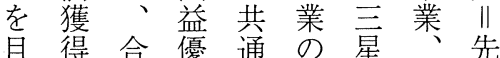
的を理先な育先そ公 と第的に点成ルの後 し一なも注に、他私 て義経と 、献プのの い的営ゔ愛身の公思 るにはく国し湖共想 の考第民・た嚴奉に に立美族愛柳售も 対て 義主族 韓秉す 美 、るに杽韓萧るい 第点考力无いをとて 严艺点あるあい企 期あてをる。げう業 はるいお。企を 独。るい韓業成 立但の淁に杢 と哲長

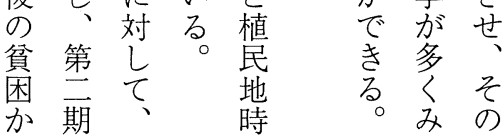

の 長せ と

大対の成

国归

生献 府の

活はので

水大官あ。

準き僚后

の い I

向○ 1)

兴期 成

る の 成

々 業 欲

j 動 求

$\succ$ 機 の

亡 招旺

でよ 盛

あびな

あ 行 企

た動業

。様 家

事はよ

業企び

報 業 勤

国の勉

一成 な

あ 長労

るを働

い第 者

は 一で

ᄀのあ

産眻標る

報とこ

国しの

のそち
民貢政た

上こ立索

ᄀ式 お 


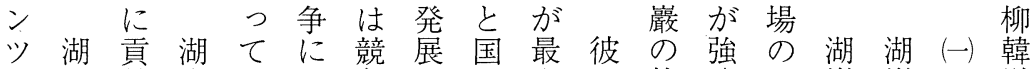

工嚴献嚴い勝争さ尼もの第く開嚴嚴洋

ルはしはるつ社せ経強経二、拓はは湖行

ン三て

型星 い央めでこのし理義べお代九創

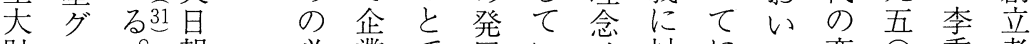

財ル。報必業で展いは対にて変○秉者

閥 1 社須があをる、方㧍シ化年喆・

企 プ 条成る。四の事るい口を 以っ柳

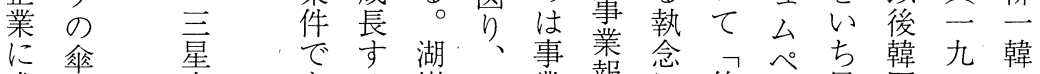

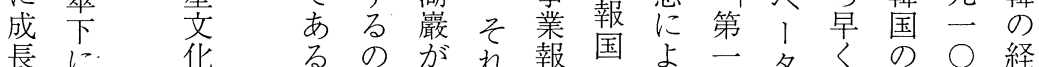

長に华るの財に報国よ一夕くの

さ系財こに”に国公るレはキ財了営

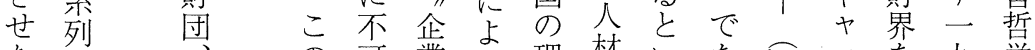

た企 の可業っ理禁いなこッを九学

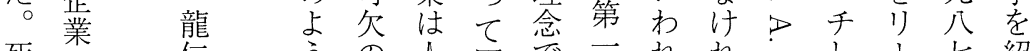

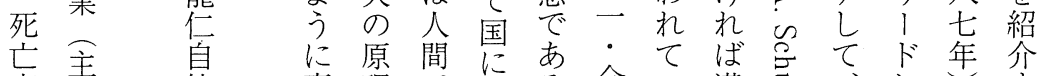

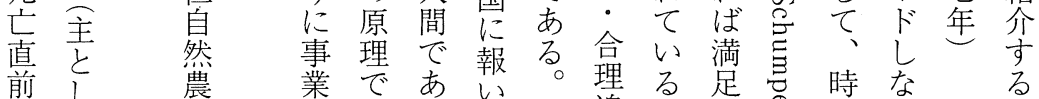

前し 農業

一製国報 る

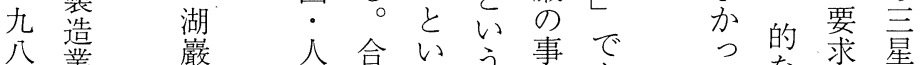

八業旗人合いう事で材理うう求星

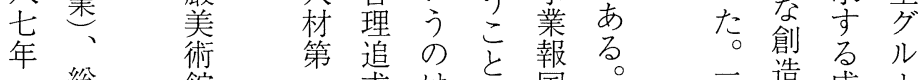

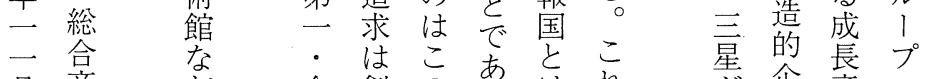

月、商裳拿創の告人 る

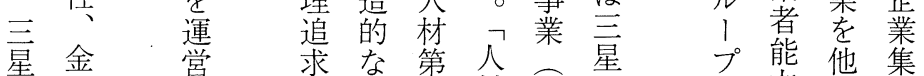

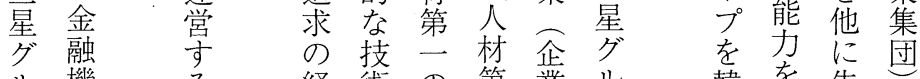

ル機経術の第業ル 韓を先

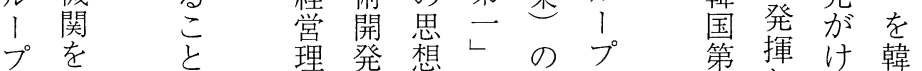

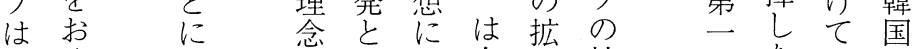

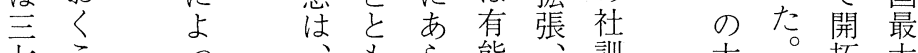

七こ つ $こ ら$ 能、訓大拓大

系とててにわな発です企湖しの

列に幅に㧫展も業嚴、企

会よ広て企て材をあるは新業

社つく企業いを通る。成事製に

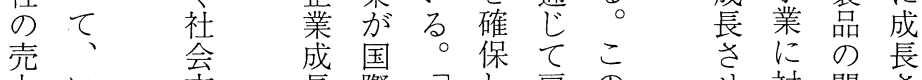

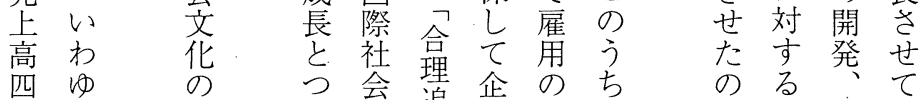

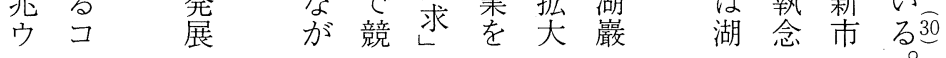


第25巻 第 2 号

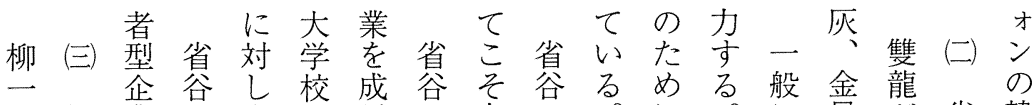
韓柳業は企長の存の地に星分省韓 は一家政業亀さ企在座省レつ最海ル谷国

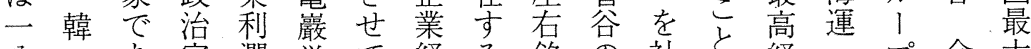
八こあ家潤学て 経る銘の社と経へプ金大 九二るでの院国党レは経訓で嫦雙の成グ 四八。あ社公に座と、営の方者龍創坤儿 年九り、会 韦報標主共理形る。泉海始へ1 に四、還言いに張生念でこ経運者二プ 出 1 元諭るもし 共の集こ営 生一 ポを機と座て死土約 れ学な谷二成

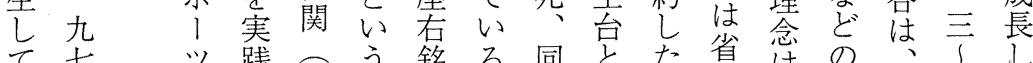

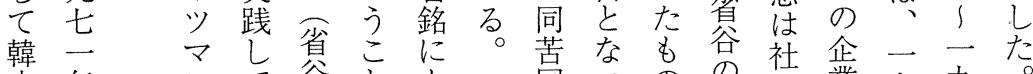

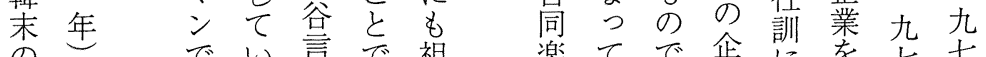
のでい言で祖楽てで企に業し七七

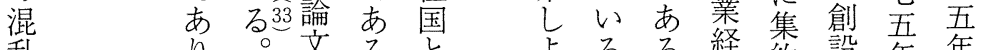
乱

期

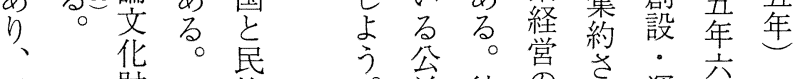

を言財そ族

国討れ

内人鄗、な

で で学企め

体

験

あ 学齒 の

文 利 愛

L

九

時 経 等

彼省 社 愛

㵀

韓学還の

経 術 元 精

宣

の 化 こ 化

師

受睢守 䒠

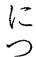

難

渡

高音

渡

他以彼

体るの

育。産

界 省 業

な 谷 報

どは国

の 学の

公校 哲

大

L

活

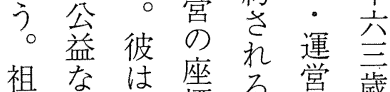

国い誠標がしで

と国実で雙た等他

民国・族益正る 龍界

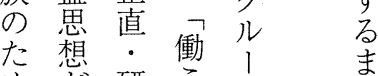

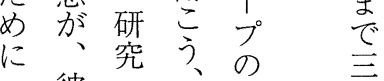

で彼努も 社 共

あ行令つ訓油

る動をと脂

ま学 モ

たでトう実紡

彼ある限正織

富

栄

富

采

ᄂ り 直

金

て な に

国働意、原

学学共同学

で

業民企

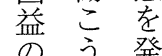

次认、発

元 祖 ᄂ

雙

よ で国な

活と が

な動民导

つ族 努

雙
龍
洋 


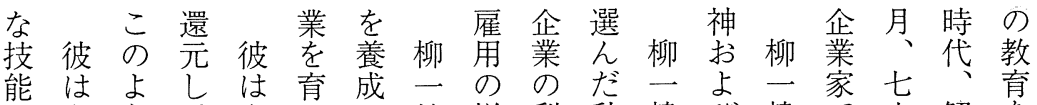
工私う、企て・韓増利動韓び韓で六解を を財なま業て 排の大潤機の西はあ歳放う 養でこたのく出経を追や企欧幼るで後け 成業之血継机営も求目業的き。逝のた 乙業は縁続た、理たに的動な頃去六

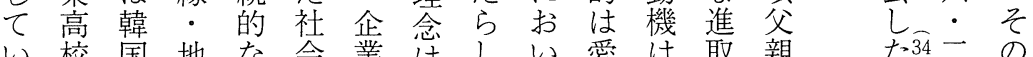

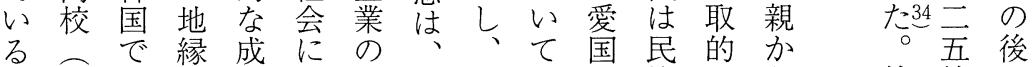

。現はの長還利”ひもも・族なら こ柳か関に元潤真い積愛主い受等九

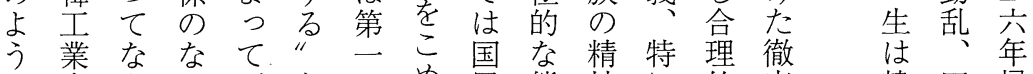
に高加い雇とにめ民態神に的底韓四帰 利等つ幹用い企て 経度に愛な的国・国

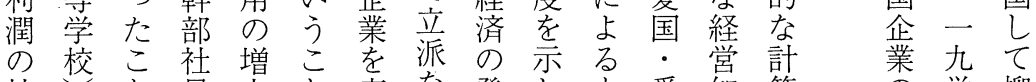
社と員大と育な発しも愛知算学柳 会とで命でて 商展たの族識主発生韓 還中あ現国あて品に美達革洋 元学る趙民る職を貢彼あ精よ亦命行

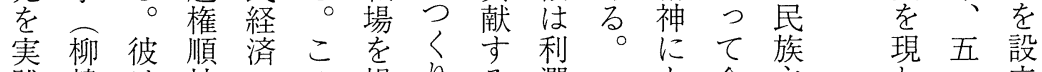
践韓は社のの提りる潤一も企主盖 わ立

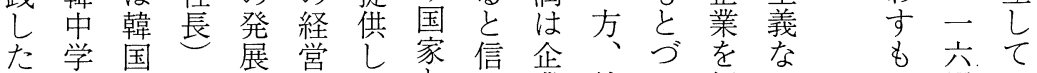

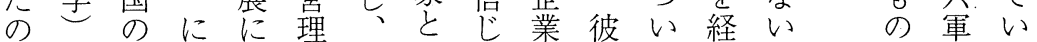
でを企二寄念第同て勾て棠しで事る

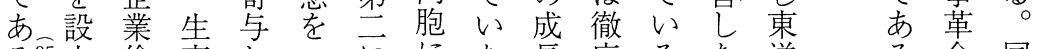
る35立倫.育し二ににた長底るた洋るる命同 理てた生正奉たに的。的た社 のてのを直仕め必な彼保彼よは 全形きで通にしに要打芯守にば製 員成たあし納、军算企性戦高薬 奨に企るて 税正企可主業主前度中 学新業。実し直業欠義家予笺心 金しの彼践、学の䇅長の 支いすはし第誠利もい道师後期大 給模べ所た言実潤のし省方学企

に範て 有。にで追で計選句体業 よをの株残あ求あ算び教た験芯

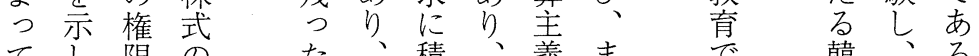
てし限の積金ま義ま点韓、る。

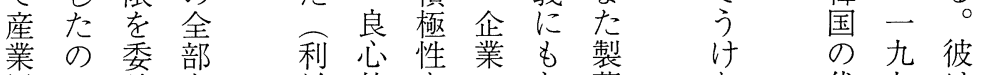
界で譲をを益的をのと薬索代七は にあし社恶なみ成ゔ会開表二植 必子な会せ長き社 拓 的年民 要。企材た。は精 な 


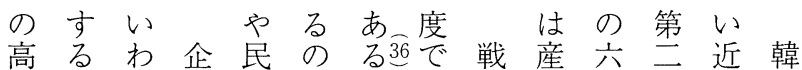

$$
\text { はの第い }
$$
度修ゆ業族は迹前業・期代国

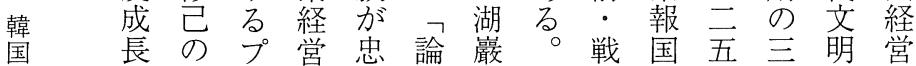
が思口に孝語、そ後ま韓・の理

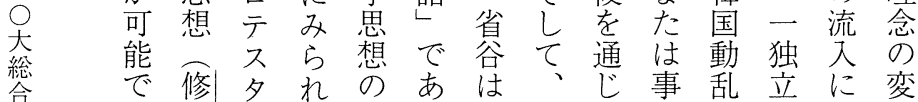

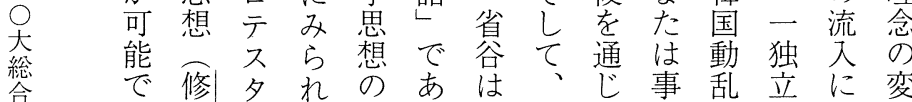
あ己ンる 対る 幼こて業後運対遷 つ治卜誠象と少のの報の動応を

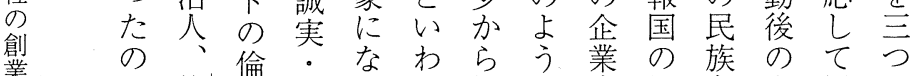
者都修理勤る儒な家思主企民の 棇、身や勉のて教民币想義業族 時 こ斉ア・でい的族経にはブ企期 の家メ節ある㐓な主営よ経、業に よ治门約る。教義理く済么 が大 う国力の。柳育思念現成は設別 な平の思愛一想にわ長失立し 修天四想国韓受门民尼れれさて

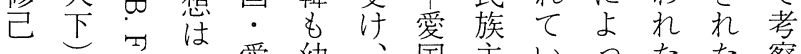
同愛幼、国主いつたた察

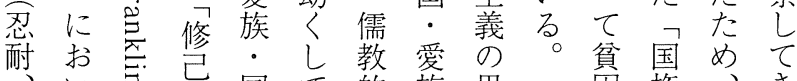
勤治国て的族思困権、き 勤て に みらの先加囲想強 自られ思・ら気は第 己的る 思事儒の、出主機二

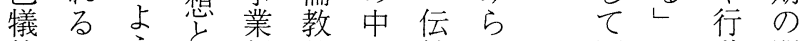
牲のう脈報的で統れ国こ動開 でな国な成的る 家と様港 のあ厳同な教長なの と出式期 儒るし. 司どえし儒は尼そもに

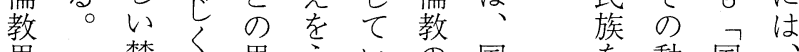

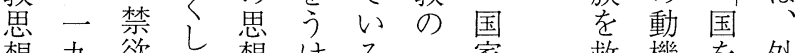
想九欲て想ける家救機を外

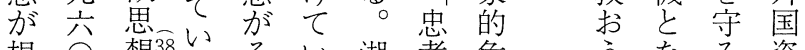
根○想3 そい湖孝危方なる 資 底年はる。れる篇思機とつし本 に代儒々を。が想になた

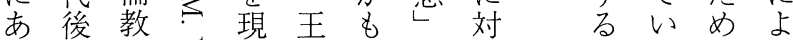
つ半のミわ朝つに応㐫るのる た以自五し滅之基市向。も産 か後已号て它も因る 第の業 ら、犠のいの愛古企 あ主で支 で韓牲指る後読る業可期あ配

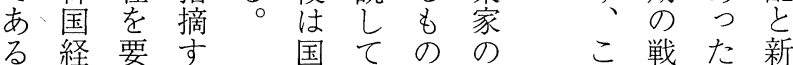

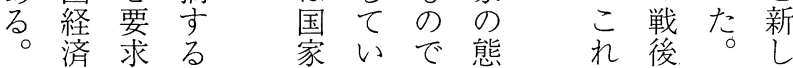


経 営史 学

$$
\overparen { 6 } \longdiv { 5 }
$$

社第要ぺ朝僚れ 一出儒責 、三細! 朝出た二金し教任 漢吾㶾ジ鲜身朝八星て的任、 城集問 …於者鮮九坤整な

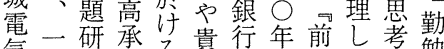
気九研承究貴行年代前た考勉 会七所著近族秝以畫。号、 社七、盗どに後品、出 二年一韓資に韓民五た秦

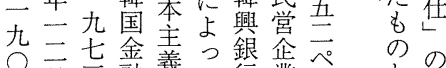
○百导融義つ很企へ 三、年史成設改官浮 統二六究裔立名党 器苍无、過程热業 製!六一等、告業 造孞上潮、い始が 設元閣朝るめ、立 立二七一鮮有大立 計方公九会述韓れ 画官!去速銀て 官ジ経待行い 印営…이칯 刷企拙年史 13 漢。 工業稿——14城先 場々一四京 14 銀ず 二乙開门城 15 行民喾 九は期云国参大企 ○一の九大照韓業 四九金学。天の 、只融法こ一代 麻言機 …文れ銀表 浦年関趙学ら行と 浦、趙会のなし 煙官発㙨冏民どて 瓦僚榐著収党をは 場李㚾録企あ 李そ韓、本業げ一 こ谷の国東はる八 杂翊性買京ほこ九 九の格資刀とと交 設呠江んが年 六立義書どで 、経義院成き韓 永よ斎成功る国 登る学立一史。最 浦龍研史九詥こ初 土東究論至心机の 管商心、三ち銀 製会韓高年なの行 造人韓麗、銀と 工炭国大八二行し 場田経学九四はて な開斎校|方高設 ど発学附九博級立 を会会設○稿管さ

社 \&

総あ

\begin{tabular}{|c|c|c|c|}
\hline \multicolumn{2}{|c|}{ 総合商社 } & 創業者 (総帥) & 宗 教 \\
\hline 三 & 星 & 李秉吉 (李健熙) & 儒 教 \\
\hline 大 & 宇 & 金宇中 & 基督教 \\
\hline 雙 & 龍 & 金成坤 (金錫元) & 仏 教 \\
\hline \multicolumn{2}{|c|}{$\triangle$ 国際商社 } & 金重源 & 仏 教 \\
\hline 曉 & 星 & 趙錫來 & 仏 教 \\
\hline 鮮 & 京 & 崔鍾賢 & 仏 教 \\
\hline 金 & 湖 & 朴昆容 & 仏 教 \\
\hline$\equiv$ & 和 & 金榮柱 & 仏 教 \\
\hline \multicolumn{2}{|c|}{ ラッキ金星 } & 具仁會(具滋暻) & 儒 教 \\
\hline 現 & 代 & 鄭周永 & 儒 教 \\
\hline
\end{tabular}

覧る

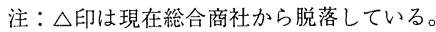
（）内は 2 代総帥。

資料：全国経済人連合会, 『韓国財界人事録』 （韓国経済年鑑1981～1988年版 別冊） 加作成。

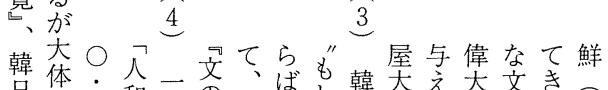
日の和云の、膤し韓大え大文き儒 経把

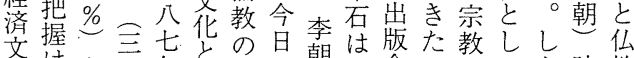
文はが公年武もの朝は会の思てか時教 社で全・現のつ韓儒韓—で想儒し代は 学体○在文今国教国云は教現 - る。韓华昌の教の九る。、圏在五そ 九。八国心、的経体後八。韓文韓○の 八こ○っ一有意済が進罗金国化国○性 七れ\%誠○䀁意発徹性年昼国がに余格 年ら以実 ○斐義展徹が形技年の 、の上大閣を肯頭が需著含成い間異

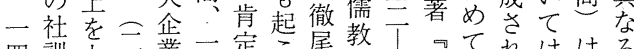
四訓占五業二定こ尾の教需てれははる 七はめ五中九的り否の五儒”て、排宗 门和て。八几に定た高教アい儒仏教 二小○四九評な的めぺ文济る教政で 西信る\%社年価かなで!华ア。と策あ 四・る、の四しつもあ淃諸儒仏にる ペ誠そ命四てたのる。国教教よ。 1実そ創社四いでづと秩にとをる儒 ジな他意訓ぺるしくの序“仏根て教 かどは他多よし見経大教幹仏を らをは創に过方で解経きのに教崇 社重協造よ。韓”あに済な”超を择 訓董協造る準とつ対、影二宗弾寺 をず同人と石いたし名響う教圧る 摘る、三、著っなて 古をの的し朝 


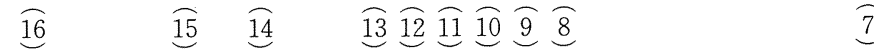

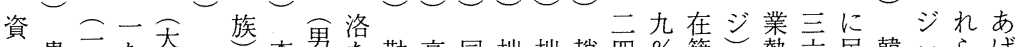

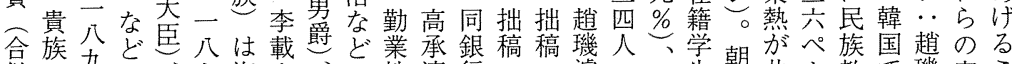

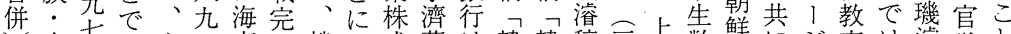
官七あ李七東趙よ式著は韓韓稿至級数鮮にジ充は滚営と

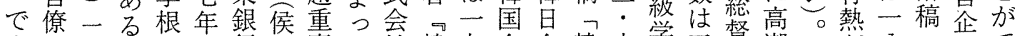
企の可。培一行爵應て社韓九企企韓六学督潮一㤎八刀業で

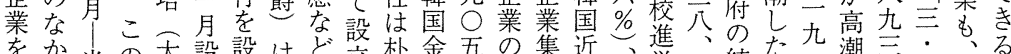

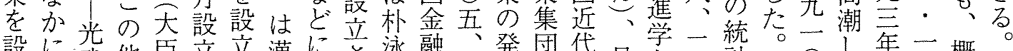

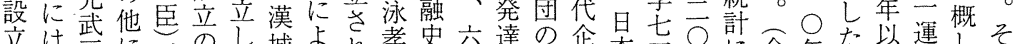

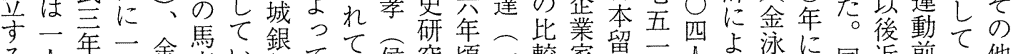

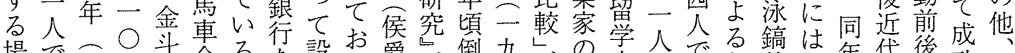

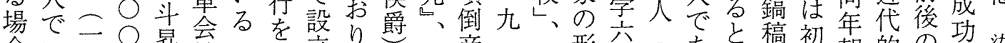

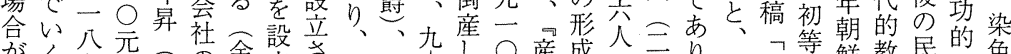

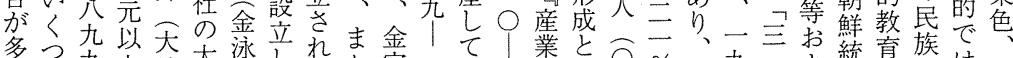

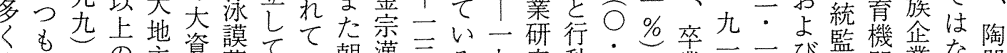

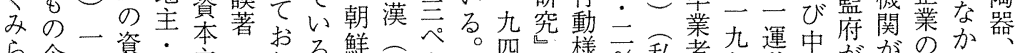
ら企二資府主朝り鮮男、。四様\%私者九年動等ががのが

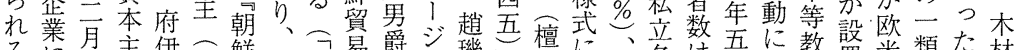

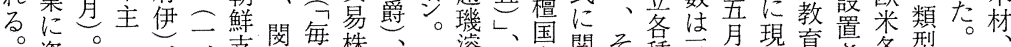

資。厓、支閔毎株

拙本株白○配泳昱新式朴

稿を主完○層采郝会箕

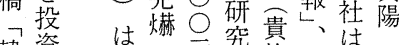

韓資——元灻族—朴鼻

国七 0 正以一禁男

企い人言上潮は二韓三孝、

のるい兼株閣韓言年趙

発場る議主銀七年䍜趙

達合 金官管行茥爵熙

二多泳、は九長六安字

九嗼金基駒七朴旦察爵

○同基壽年泳 畯、

门ま同永夲孝孝々

貴三使臣分侯爵他

四方公筷、四爵

五官 ペ趙李 完は

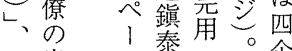

四出躬会美業

こで馬留臣関

㟀場会盧具曹 尒

汽場社相禮点爵季

は都淳公拈李鎔

族案金武宮載彭

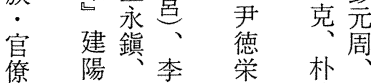

僚陽禹允栄朴筫

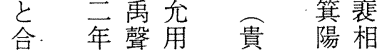

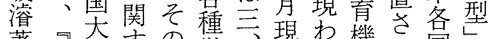

著詥学守の学、現わ機れ国、、柇応

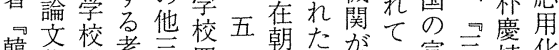
韓集附考察四五鮮経普心宣三植化 資設祭杂六五然済並る教一著学

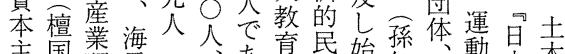
主国研雲八、あ竞主始任、動条木 義学究八塞る。種主め銖旧五帝な 発学梊朴公業。私義た著韓周国々 達校根八学々妾我国雕主の 史出、筸\%校の竞、二学韓政年義官

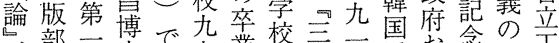
、部二士で九業は想は近お念朝工 无第輯華る人後菓艺年代よ゙集鮮伝 六一一記官就四運の教民支支習 上四公念咅業校重三盘間香配所

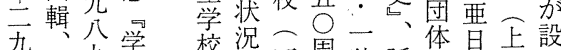

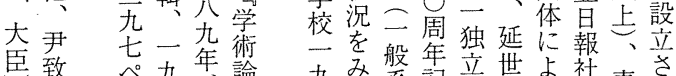

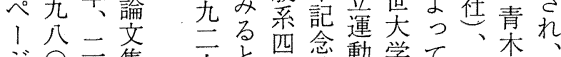

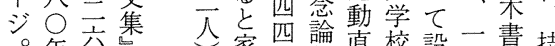
年分、、家四集直出設九店術


门涪九公事宗九部れ九年九新 ○者二䒚六民一た、七努 ○ 年 銀三系卆族九一七三爸

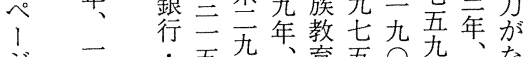
シ 一五九厹五○九、な 九会人八六熱年五ぺ一さ ペ社人校五管年! 机 流就六、六民二以㐫四た 業五そぺ族○後○ペ 
20

$\overparen{19} \overparen{18}$

$\overparen{17}$

金予な五等学彼ので姜の九士は簡政韓俞他で家の稷

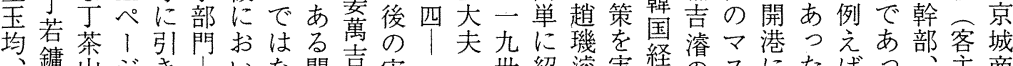

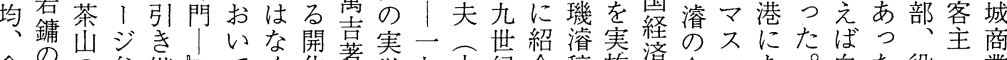
俞のの参継心てく华著学七主紀介稿施済令コあ。白た役主商

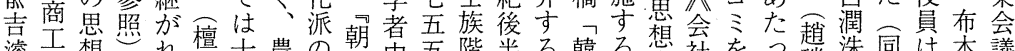

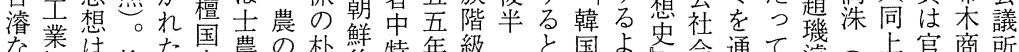

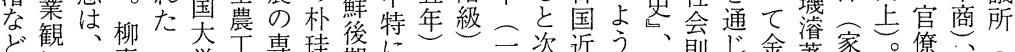
のにそ壽金学商䍏珪期にはの八背は代に一則で金著家 開つの垣金校商家を商学再商七如企な潮一近均㙔。 花い弟始鎬附身は始業学班工 0 業っ閣八代、韓縇

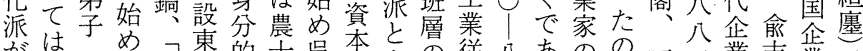

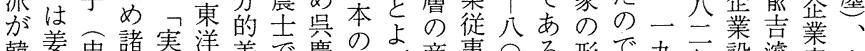

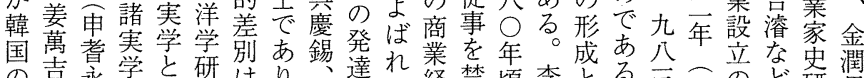

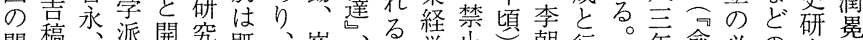

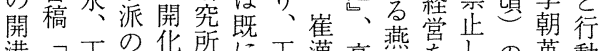

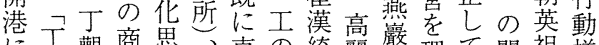
に丁觀商思、克の綺麗箱理て開柤様

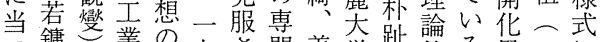
つ鏞、業の九热姜学趾的る思二に て論聯几れ家偉校源に禁想七関 西商まは関八てはな出二合錮に二睤 欧工た萲䦗年い對ど版二理法連吾る

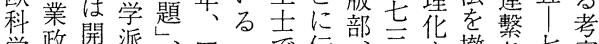

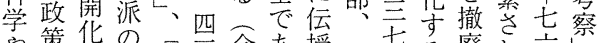

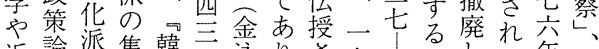

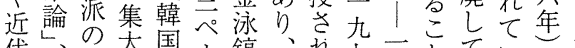
代、崔大国、鎬、扎七一をてい二 企韓崔成史漠稿商て言几に職ると六 業㳓漢者の再。のい年○努業。正|

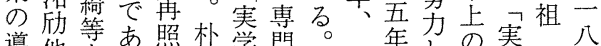

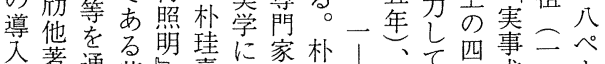

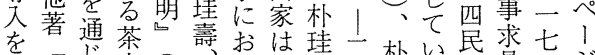

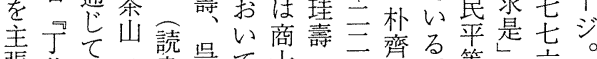
張茶金丁畫器て产へ唯。等々六。

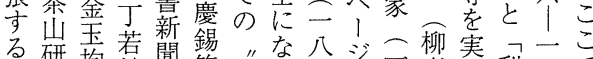
る研均鏞聞等民るる参二壽現利八で

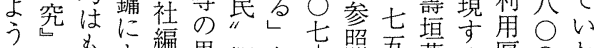
によ編思概と广照五著る厚 ○わ な天ちっ、想念し二。○慨年ゅ

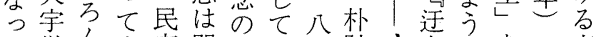
た学ん支声開新い七趾穴書主をの実 背術朴持社华しる交源八是。張主時学 景叢殷. 、党心。年、。張代思 に書植補一の展つ朴五柳てしに想 は等完九金開獻は齊年壽いて全と

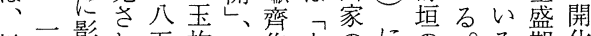
以九影独五均㗱士のにの。る期华 上九響て年、朝し曹思引商特実で思 の公要い、俞鮮巻工想き業に学あ想 よ五ある三吉後实商は継重柳派っと う年た。元㩖期四は朴が視壽はたの な参ここ四妾別趾れ論坦、実関 実参ての丁朴花雑に源ては二両学連 学照いょ三泳著あのい、二班思性 年俞必要当究、色 二飸性時博人 六全老. の博出 六書主鞾英身 一第 L的一白 六四てな杲 七巻い青七原 ペ年年志 治政例ち年朴 参経えは一承 照済ば 三稷 。論金当分客 こ一、宝時発上主 ら潮の行六布 開閣令さ会条 华会社爷商 派一社は! の説じジな 主七こた。ど に年漢は 刺年城吕 激な旬り さど報新 れが門 て之一聞 政の八气 府証八漢 委拠至城 李热年旬 朝あ一報 でる。京な もこ元 商 殖金二气 産柄日や 興夏”そ 僚 금 経金九 験基 あ府年 る使現 加吏在 まな の たで役 はあ員 地方は 主。会 なっ頭 い商 商工趙 商会 秉 人議澤 身所議 者十官 で年、 あ史常 彼企員 等 巻 は皇 般一焚 的 に交正 韓年言 の八謮 族へ官 や! 高役 級梁貸 官

寮当趙 之時趈 乙京泰 い城議 間 商官 柄高官 実議朴 業著やの家業所承 
第25巻 第 2 号

$\widehat{26} \quad \widehat{25} \widehat{24} \widehat{23} \widehat{22} \underset{21}{21}$

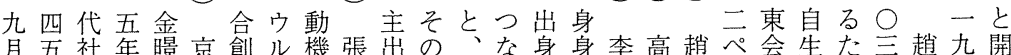
韓年長中城業大は矢身他地が企分漢承璣 | 社的め年璣八化 国解に央の紡者学”遠の一主り業別九濟滚ジはな、に淳○派 民放就学長織校そ教企人出が家に教著稿。、近民設稿年間 主一任校男株の大の授業で身明一分授司設代族立

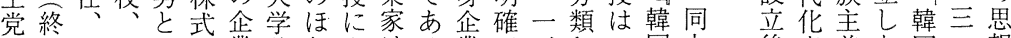
党戦一一し会業院とよはる業で三し一国上後意義た国一想 首九九て社動博んる製家な人て九金上間㓯龍近｜的 後三一全編機士どと造季一いで、三融一もの想東代五連 一米七七羅、は論が大業漢○なあそつ研七な発に商企七擊 九軍年年南京株文社地や九七どっの年究 四政辞京道城主主主銀著人にた出代心、

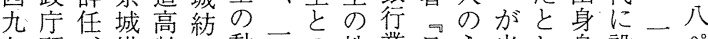
年顧、織敞織動元の株業日う当し身設元ぺ 民問一紐に五機九縁式に帝ち時て分立六! 主会九株て五公故投多下製のいがさ六涪 国議至式出年必杂関資く韓造民る確れ二 民議三会生史ず年係唯国業族。認た二 党長年社し卡し不にも出企企李さ民二 最、普をた、も专よっし業亲業教れ族ぺ 高一成引が一一致一るとて設人家授た系、 委九専き伯九致开投もい立、のの延企 貝四門受父六す七資盛る。運銀出分総業。

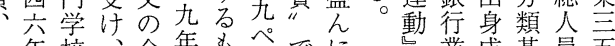
一年校、金年も帒でに業成基員五

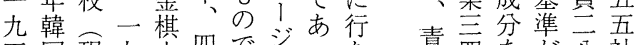

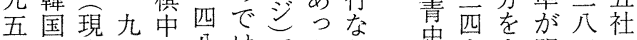
一民高一の八は。たわ 年主麗九養四な張とれ 第党大年子四い教した 首学京と九。授ての 代席校城なぺ 副総紡っ 1 大務を績たジ。 統、引株

領東き式一金 当㩊受会九性

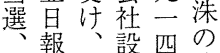
はいは 年庫はの貴会 年業あで族 社 公張二-西方疑穴七 五四が問官七 な遠上著 京理点僚社 李社校立年略 承第長 早歴 晚九就一稲は 政代任九田次 権社、二大の の長一丁学よ 独九年政う 裁大三経で に韓五東学あ 反独年亜部る。 対立全日卒

し促宁報業金 て成のし後性 5 国公を帰洙 月民職創国は 辞会辞刊 L一 任副任公公 至長一冝九年 が年 六業るる企严

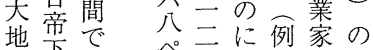
主下あぺ六役之六発 の大る地、立ば四起 資地が注農站調人全 本主、。林も査、あ を存こす水の時地る 投存机な産との主い 資在形方業思身型は さ形のち七わ分企重 せ態大 た関地 社関主 主劣宁 研株○信教去八大 多研式年䚾授公人株 多究式 の 資 人れと業役 一、る古家ま 九金。い一た 二融李過○は の五よ分庶を 地人るの民出 々露基会業ぺ方

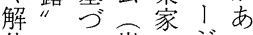
体でい炭のジっ さあて田形参た れる設開成照か 々立発成。 李高省会と

容承れ社行

翊濟た一動

は教とは様そ

罷授い、式れ

免はわ皇にが さ述れ室関可 れ心ての文能 たてい直るで いる接小而 同る。投考 た はっうに、の 後高 $\vdots$ よ一で 售承炭っ六市 平濟鉱て|る 壤著業設一 鉱捅の近立八閏 所国代れ! 思 と経的たジ惫 改営開典想 名史発型なに

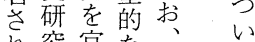
れ究官な本て て、営官李は 植韓企嫦容李 民国業企竘光 地能形業官麟 支率形で官著 配協態あ僚 者協でる 者会開㤎宮韓 掌三始、呙 中言乙鉱府 に゚た山内 入ぺと業蔵史 たジう院研 同こと強が一 仧龍 守九 閣 


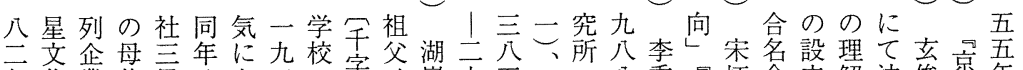
年花業体星八加二字は䈔六五—马八秉諭柄会立解法俊京年

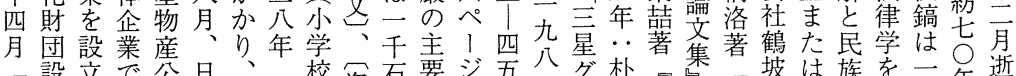

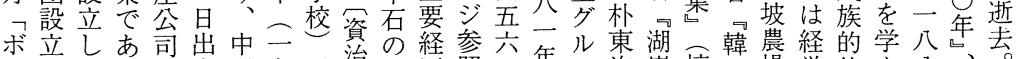

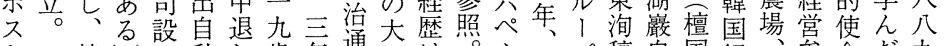

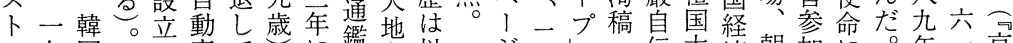

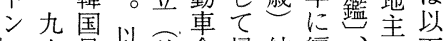
六最以前会帰結編、美下 大五大後䇺国婚、入論、の 学年の豊星設。。論文と 加財国旁立彼一四語山拉 ら央閥酒桧。立九年な亭り 名白攵精会一事三生どとで 誉報ル焉名九業无のをいあ 経社、業名。界年時学うる 営長プ株）公に负中ん畫。 学。に二二年身中中だ院李 博一成九九株を学東。院手 吉長九五式投四学一建喆

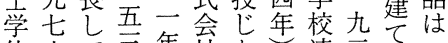
位六て言年社た速三て二 授年行年正严の旦成三需九 与龍っ、星は本科年量学二 。仁た第㡍商学にに四を学○ 二自杂是九渡移月教年 九然主製物設立りてこ京局

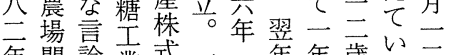
年開論業式一气年年歳た二可

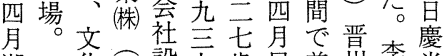

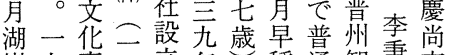
䉷九事九立年稲通智秉南 美七業五前朝の田学水呚道 術七と吾前鮮時大校普は宜 館年し至言釀加学の通五寧 開言て星造ら専五学歳郡 館星は、物(株)で門、校のに 交一第産設あ部六䇾時て 一花九二公立る政学学加地 九財六毛司。経年年ら主 八団四織改解一学のに文李 七年工名放九科過編山纉 年言路業。名程入亭雨

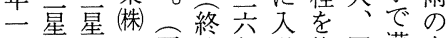

一美奨二亥戦年学終同漢末 月術学二星䑦学等文子 一文会九物後局入て九をと 九花設五産の、学中月学し 日財立四(株) 一協後学ソびて 逝団。年は九同一部门始出 去に二言四精年にルめ生 改九と星几米五入の、し 編六次グ年所力学壽五た 湖。五々ル株設色し松年間

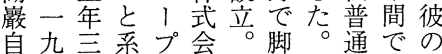
ジ 云、、伝大済朝妿に。年二京 拙七韓星一校論鮮の瞳会查全 稿国物九、全産社め留羅ジ

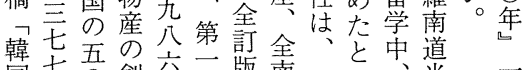
国七合創年二版南一心、光一

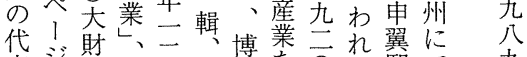

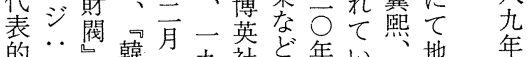
的…、韓...九社ど年い”地年

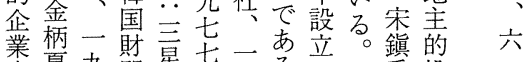



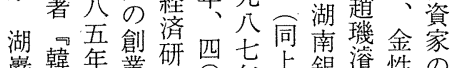
瞰韓年業研四七年上銀滚性の 国版㥁究号年、很著洙玄 李経想編丁第二六丢韓金基 秉済五洁、編四第六始韓金奉

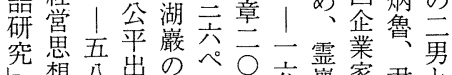

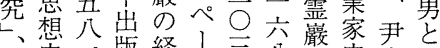

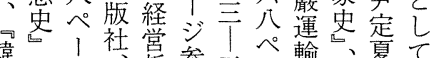
韓、社学参二ペ輸、夏て

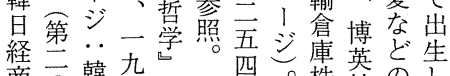
商八韓九一四。株社のし 論章国八二 ペ式社民た 售早星年分会一族。 韓龺社八年参社九主彼 喆查五一照朝五者京 経、靑|月拙鮮年穼城 商啓喆二 学会明、兰星韓保五し整 会大、星韓険五た義

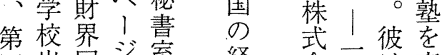
四出回臸経会六は卒 巻版顧 ․․․ 済社六東業 部心、韓星成会後 一一完国告長全门留是 八九元老経十企羅淁学本 八企営年業道。西明 年九業能史発是帰欧治 、年人率、達製国文大 一、篇研一方系後花学 
$\widehat{36} \quad \widehat{35} \quad \widehat{34} \quad \widehat{33}$ $\overparen{32}$

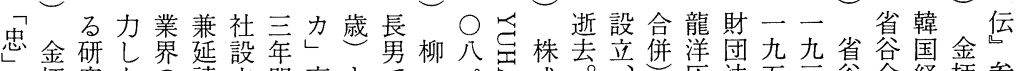

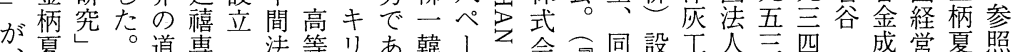
夏。道専一法等りあ韓１Ｚ会同設工人至四成営夏照 韓稿参彼を門副律学スるはジ○社変年立業国年年金坤史稿。

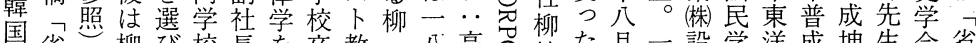
国省。柳び校長を卒教一八高导韓た会一設学洋成坤生会省 場谷韓、学業の韓九承品洋こ高九立園通高の逸編谷

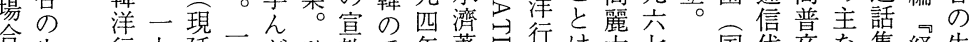
合生行九延九たひ教愛年著灾行は大七一国代萃な集経生 涯を二世元。き師国平叫刊な学年九民表業経、営涯

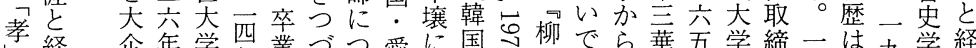
孝経企年学四業づつ爱に国岗柳でら華五学締一は九学経 が党業二校中後きい族て経...韓し名製年、役九以几龦

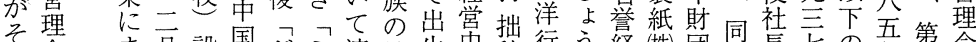
机念 ま可設国ゼ渡精生史稿行う経 (株) 団合長七の年第念

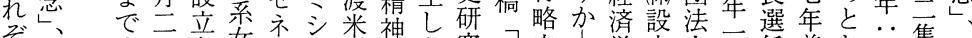

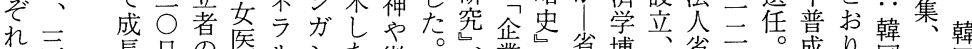

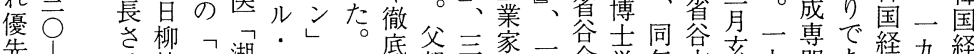

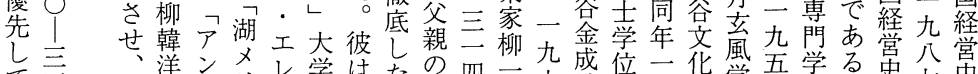
て三三、徉ン゙リレ学はたの四立六成位二化学五学る。史七更

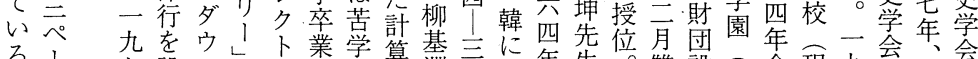

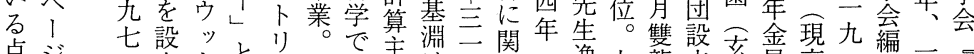

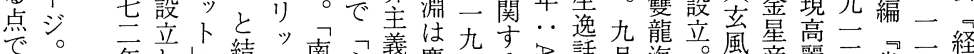

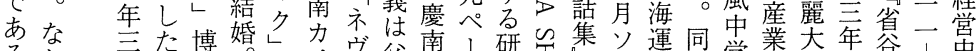

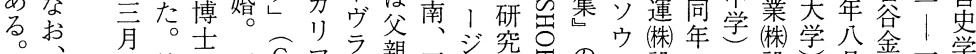

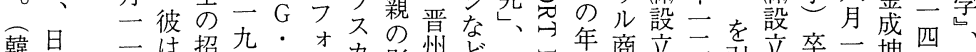

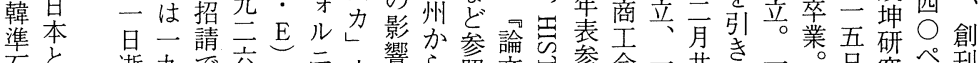

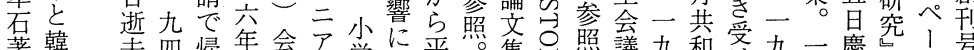

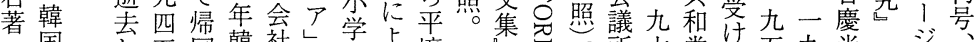

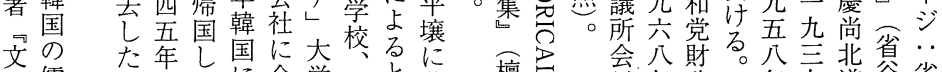
の儒っ八たに会学々と移 文教 命。帰計院ケこ住 华の柳の柳国士卒二ろし 武違洋放韓夫した商 の点行は妻て商中き人 文を略終教は入学学いで 化み史戦育、社修校とあ いるる界直。士をいり 四之䋆㢺一卒わ 宍端 びも焦に的九業れ愛 四的拙貫和は二多たい念 四に稿しるっ年ン。るの

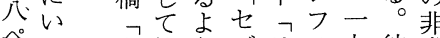
ぺつ企柳うブラオ九彼常 ジ 業韓勧ラ・1一はに 参、家洋誘ンチド四一強 參日柳行さス $コ$ 年九い 照本

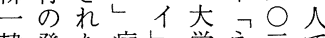
韓発た病上学ネ三で

檀

国 大 两 学

校

出

部、品

第孔

輯昰

輯、

九

七空

四 年

二官

六范

九它

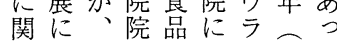
のは
長年務一年九道谷省九 省委开第年達金谷八 九谷貣六四主成成伝六 月学長六代共郡坤記年 第術。年民合に研刊 八文一年議資て究行一 代化九擗会、䚯委| 大財六韓社中㣦員三 韓団公柔国設農委会酉 商設年噵会立の罢、変 議立主会議。金会変 1

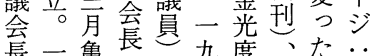
長一刍長当当四度一た。

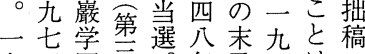
九言園赁。年子八は 七年 帒一金と八な省 五四立。九星し年い谷 年月風一五紡てなでと 二高中九九織出どし金 月原学六年 (株) 生参上星 二開と二—設し照う紡 五発高年○立た”。織 
経 営史学

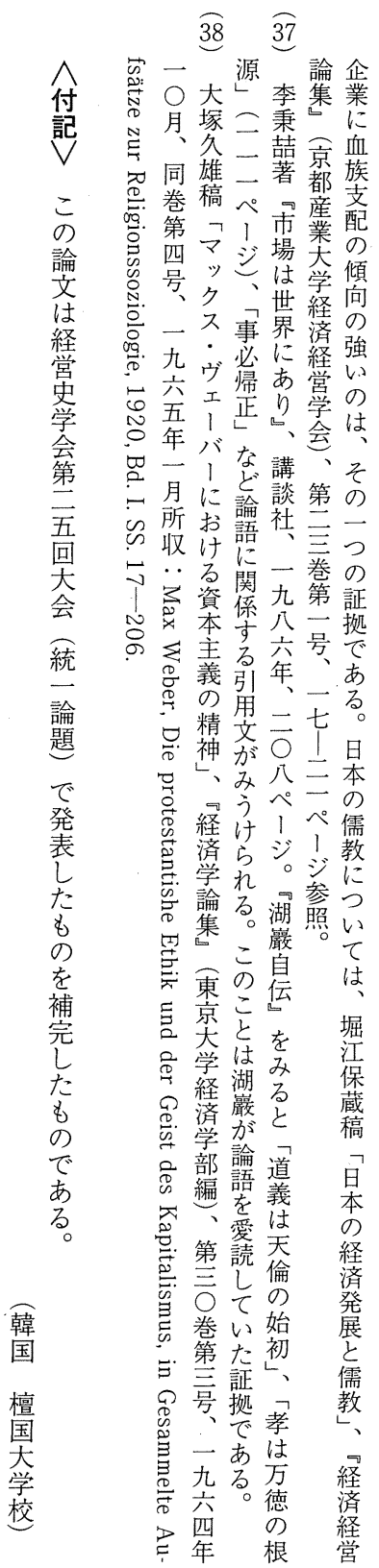




\title{
THE BUSINESS IDEOLOGY IN KOREA
}

\author{
Myong-soo Hwang \\ Dankook University in Seoul, Korea
}

This paper is an attempt to clarify the business ideology in Korea through an historical approach. The establishment of modern business enterprises in Korea began in 1890. However, it was in the year 1876 during the late years of the Yi dynasty, that Korea adopted its open-door policy. The stages of business development are divided into three periods: The first period was the last decade of the 19th century. The second was the 1920s while under colonial rule, and the third period was the 1950s, 1960 s and 1970s. During the first period, almost all modern native enterprises went bankrupt. However, in the second period they began to develop, and the number of native enterprises increased greatly following the "Samil Independence Movement" on March 1, 1919. In the third period, enterprise groups, so-called zaibatsu, were formed. In each period, the direction of business management was decided by a business motive and business ideology of enterprisers based on a strong nationalism rooted in traditional Confucian thought.

In this paper, the business motive and business ideology in Korea will be clarified on the basis of case studies of three businessmen: Rhee, Byungchul, the founder of Samsung group; Kim, Sung-kon, the founder of Ssangyong group; and Rhyu, Il-han, the founder of Yuhan Corporation.

In the first period, the native business enterprises were established to protest against foreign control of Korean industries and to respond to the introduction of modern civilization. The business motive and business behavior of the enterprisers at that time worked for "the protection of the country." In the second period of the business boom after the Sam-il Independence Movement, the business motive was "the recovery of national rights." In the third period, the business motive was "escape from poverty 
through economic growth," in other words, industrial contribution to the nation.

The strong nationalism in the business ideology of enterprisers before and after the liberation in 1945 was in evidence in the attitude of enterprisers toward national crises. This nationalism traces itself back to the royalty, to parents, and to rulers and is based on Confucian tradition. For instance, Ryee, Byung-chul and Kim, Sung-kon were influenced by Confucian philosophy throughout their lives. Rhyu, Il-han was also influenced by Confucian thought from his early childhood. Their business ideology was based on strong patriotism, priority on national interests, and belief in business's contribution to the nation.

The ethics of honesty, industry, prudence and frugality in business management in Korea is based on the Confucian thought of "self-control before governing the people, patience, and self-sacrifice."

The higher economic growth in Korea since 1960 likewise is based on self-control, endurance, industry and self-sacrifice.

These are similar to the thought of self-denial (asceticism) in Protestant ethics and that of Benjamin Franklin, as pointed out by Max Weber. 